\title{
MR
}

\section{Association of tumor necrosis factor- $\alpha$ gene polymorphism with osteoarticular tuberculosis prognosis in a Hebei population}

\author{
Y.J. Lv ${ }^{1}$, S.J. Liu' ${ }^{1}$ W.N. Hu ${ }^{2}$, G.P. Zhang ${ }^{1}$, Q.Y. Ren², L.D. Zheng ${ }^{2}$, \\ Y.C. Zhang ${ }^{1}$, R.Q. Li $^{1}$ and Z.K. Zhang ${ }^{1}$ \\ ${ }^{1}$ Orthopaedic Department, The First Hospital of Hebei Medical University, \\ Shijiazhuang, Hebei, China \\ ${ }^{2}$ Radiology Department, The First Hospital of Hebei Medical University, \\ Shijiazhuang, Hebei, China \\ Corresponding author: Z.K. Zhang \\ E-mail: zhangzhikun_1@163.com
}

Genet. Mol. Res. 15 (4): gmr15048937

Received July 1, 2016

Accepted September 12, 2016

Published October 24, 2016

DOI http://dx.doi.org/10.4238/gmr15048937

Copyright (C) 2016 The Authors. This is an open-access article distributed under the terms of the Creative Commons Attribution ShareAlike (CC BY-SA) 4.0 License.

\begin{abstract}
This study investigated the association of tumor necrosis factor- $\alpha(T N F-\alpha)-308,-238$, and -863 polymorphisms with osteoarticular tuberculosis (OA-TB) prognosis in a Hebei population. Genomic DNA was extracted from venous blood samples of 120 OATB patients and 100 healthy volunteers. $T N F-\alpha-308,-238$, and -863 were analyzed by PCR-restriction fragment length polymorphism; genotype and allele frequencies were calculated. Serum TNF- $\alpha$ level was significantly higher in OA-TB patients $(283.16 \pm 51.68 \mathrm{ng} / \mathrm{L})$ than in control $(122.54 \pm 54.65 \mathrm{ng} / \mathrm{L} ; \mathrm{P}<0.05)$. Higher frequency of $T N F-\alpha-308$ GG genotype in healthy volunteers $(91.0 \%)$ than in OA-TB patients $(79.2 \%)$ indicated that it was a protective factor against OA-TB $(\mathrm{OR}=0.405,95 \% \mathrm{CI}=0.147-0.657, \mathrm{P}=0.007)$. Higher frequencies of $T N F-\alpha-308$ GA genotype and $T N F-\alpha-308$ allele (A) in OA-TB patients (20.8 and $10.4 \%$, respectively) than in healthy volunteers ( 8.0 and $5.0 \%$,
\end{abstract}


respectively) indicated an association with increased risk of OA-TB (OR $=3.112,95 \% \mathrm{CI}=1.520-6.343, \mathrm{P}=0.003 ; \mathrm{OR}=3.109,95 \% \mathrm{CI}=1.676$ $6.538, \mathrm{P}=0.006$; respectively). Haplotype association analysis of $T N F-\alpha$ polymorphisms (-308/-238/-863) showed a higher frequency of $T N F-\alpha$ AGA in OA-TB patients (12.1\%) than in healthy volunteers $(3.5 \%)$, indicating that it was a risk factor for OA-TB $(\mathrm{OR}=4.201,95 \% \mathrm{CI}=$ 1.80-9.91, $\mathrm{P}=0.010) . T N F-\alpha-308 \mathrm{G} / \mathrm{A}$ and $T N F-\alpha \mathrm{AGA}(-308 /-238 /-863)$ were associated with a predisposition to $\mathrm{OA}-\mathrm{TB}$, which could aid clinical detection, prevention, and prognosis of OA-TB.

Key words: Tumor necrosis factor- $\alpha$; Gene polymorphism; Prognosis; Osteoarticular tuberculosis

\section{INTRODUCTION}

China is one of the 22 countries with a high-burden of tuberculosis (TB) and has the second highest number of TB patients in the world (World Health Organization, 2013). Osteoarticular TB (OA-TB) is one of the main types of extrapulmonary tuberculosis. There are about 30 million TB patients, of which 1-3\% have skeletal involvement (Tuli, 2002), with causes that are directly related to poverty (Cheng, 2011).

Madan-Lala et al. (2014) reported that in the pathogenesis of OA-TB, Mycobacterium tuberculosis spreads regionally through lymphatic vessels or through primary lesions of lymphoid TB. In patients severely afflicted with OA-TB, without therapy, the disease can easily cause the malformation of spine and limbs, limit joint movement, and even lead to paraplegia. However, early diagnosis and identification of OA-TB are difficult to perform (Raja, 2004; Garg and Somvanshi, 2011).

Tumor necrosis factor- $\alpha(\mathrm{TNF}-\alpha)$ is a pleiotropic factor secreted by active macrophages. It not only participates in the resistance of macrophages to M. tuberculosis and tuberculous granuloma, but also induces the apoptosis of macrophages and the release of other cytokines (Li et al., 2013). The production of TNF- $\alpha$ is associated with the polymorphisms in its promoter region, which influences its transcription and expression (Garg and Somvanshi, 2011). The polymorphisms of $T N F-\alpha$ have been related to the pathogenesis of many diseases. $T N F-\alpha-308 \mathrm{G} / \mathrm{A}$, located in the promoter region of $T N F-\alpha$, was primarily described by Wilson et al. (1993) and was rediscovered and identified by Pantelidis et al. (1999). TNF- $\alpha-238 \mathrm{G} / \mathrm{A}$ is another common polymorphism (D'Alfonso and Richiardi, 1994), and TNF- $\alpha-863 \mathrm{C} / \mathrm{A}$ has been correlated with lower TNF- $\alpha$ levels (Heesen et al., 2004).

In our study, we focused on TNF- $\alpha-308,-238$, and -863 in OA-TB patients from the Hebei region of China. We investigated the association between the generation of TNF- $\alpha$ polymorphisms and the development and treatment of OA-TB, providing possible clinical interventions with evidences.

\section{MATERIAL AND METHODS}

\section{Patients}

In total, 120 patients (72 males and 48 females of average age $40.1 \pm 8.5$ years) were

Genetics and Molecular Research 15 (4): gmr15048937 
hospitalized in the Orthopaedic Department of the First Hospital of Hebei Medical University from January 1, 2011 to December 31, 2015. These patients were diagnosed with OA-TB, including cervical TB (Figure 1), lumbar TB (Figure 2), and spinal TB (Figure 3), based on their case histories, X-ray results, bacteriological examination, and histopathological examination. In total, 100 healthy volunteers, 70 males and 30 females, were included as controls. There was no significant difference in the gender and age of the cases and controls. Informed consent was obtained from every patient and volunteer.

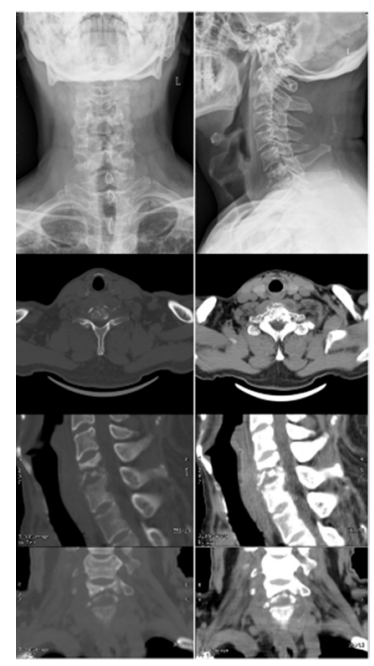

Figure 1. Male, 57 years old, with lesions at the 6th and 7th cervical and adjacent vertebrae. The cervical spinal cord was pressed. Diagnosed as cervical tuberculosis.

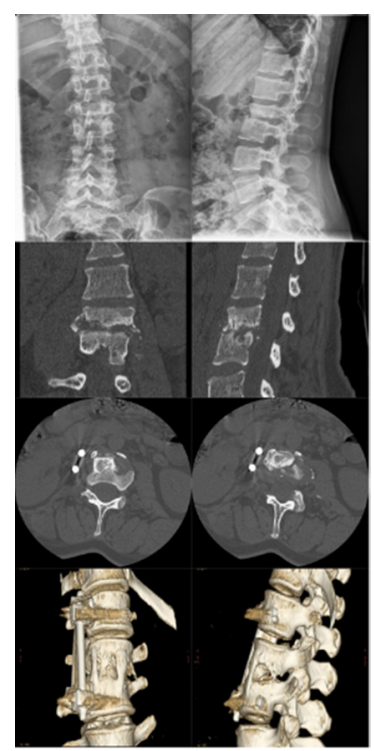

Figure 2. Female, 35 years old, with the 2 nd and 3rd vertebral bodies damaged. Diagnosed as lumbar tuberculosis. 


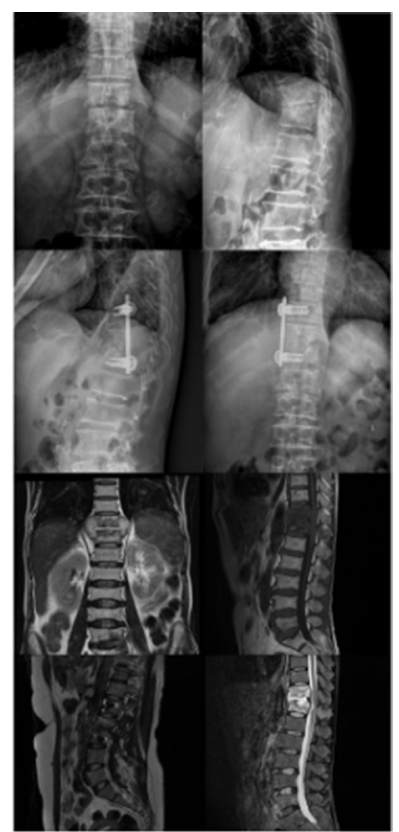

Figure 3. Male, 64 years old, with the 11 th and 12 th thoracic spine, the 5 th lumbar vertebra, and the 1 st sacral vertebra damaged. Diagnosed as spinal tuberculosis.

The following inclusive criteria were considered: 1) the patients had their ancestral home in Hebei; 2) there was no blood relationship among the patients; and 3) the patients had normal liver function, did not have HIV, autoimmune diseases, and/or diabetes mellitus, and had no history of the long-term use of hormones.

\section{Genomic DNA extraction}

Venous blood $(5 \mathrm{~mL})$ was collected from each patient and volunteer at 6:00 a.m. in an EDTA- $\mathrm{K}_{2}$ anticoagulant tube (BD Bioscience, Beijing, China). QIAamp DNA Blood Mini Kit (QIAGEN International, Hong Kong, China) was used for genomic DNA extraction, according to the manufacturer protocol. The extracted DNA was stored at $-20^{\circ} \mathrm{C}$.

\section{PCR-restriction fragment length polymorphism}

The complete gene sequence of TNF- $\alpha$ was obtained from the NCBI database. The primers were designed using the Primer 5.0 software and were synthesized and provided by Invitrogen (Thermo Fisher Scientific Inc., Shanghai, China). The primer sequences are presented in Table 1. PCR was performed on a total volume of $25 \mu \mathrm{L}$, including $12.5 \mu \mathrm{L} 2 \mathrm{X}$ PCR Mix (Thermo Fisher Scientific Inc.), $1 \mu \mathrm{L}$ forward primer $(10 \mu \mathrm{M}), 1 \mu \mathrm{L}$ reverse primer $(10 \mu \mathrm{M}), 2 \mu \mathrm{L}$ DNA template, and $8.5 \mu \mathrm{L}$ double distilled water, in a thermal cycler (Aeris; Esco Micro Pte. Ltd., Tianjin, China). PCR conditions are given in Table 2. PCR product was separated on a $1 \%$ agarose gel and was analyzed by a gel imaging system (Thermo Fisher Scientific Inc.). The residual product was stored at $-20^{\circ} \mathrm{C}$. 
Table 1. Primers for PCR-restriction fragment length polymorphism of $T N F-\alpha-238,-308$, and -863 SNPs.

\begin{tabular}{l|l|l}
\hline SNP & Primer & Sequence \\
\hline \multirow{2}{*}{$T N F-\alpha-238$} & Forward & 5'-CCGTGCTTGGTGCTTTGGACTA-3' \\
\cline { 2 - 3 } & Reverse & 5'-AGAGCTGGTGGGGACATGTCTG-3' \\
\cline { 2 - 3 }$T N F-\alpha-308$ & Forward & $5^{\prime}$-AATAGGTTTTGAGGGGCAAGG-3' \\
\cline { 2 - 3 } & Reverse & $5^{\prime}$-AGGGAGCGTCTGCTGGCTG-3' \\
\hline \multirow{2}{*}{$T N F-\alpha-863$} & Forward & $5^{\prime}$-CGAGTATGGGGACCCCCC-3' \\
\cline { 2 - 3 } & Reverse & $5^{\prime}$-GAGTATGGGGACCCCCA-3' \\
\hline
\end{tabular}

SNP, single nucleotide polymorphisms; TNF- $\alpha$, tumor necrosis factor- $\alpha$.

\begin{tabular}{|c|c|c|c|}
\hline No. of cycles & Step & Temperature $\left({ }^{\circ} \mathrm{C}\right)$ & Time (s) \\
\hline & Pre-heating & 95 & 60 \\
\hline \multirow[t]{3}{*}{10} & Denaturation & 95 & 15 \\
\hline & Annealing & 65 & 50 \\
\hline & Extension & 72 & 40 \\
\hline \multirow[t]{5}{*}{20} & Denaturation & 95 & 20 \\
\hline & Annealing & 59 & 50 \\
\hline & Extension & 72 & 30 \\
\hline & Cooling & 4 & - \\
\hline & Pre-heating & 96 & 60 \\
\hline \multirow[t]{3}{*}{5} & Denaturation & 96 & 25 \\
\hline & Annealing & 70 & 45 \\
\hline & Extension & 72 & 25 \\
\hline \multirow[t]{3}{*}{21} & Denaturation & 96 & 25 \\
\hline & Annealing & 65 & 50 \\
\hline & Extension & 72 & 30 \\
\hline \multirow[t]{4}{*}{4} & Denaturation & 96 & 30 \\
\hline & Annealing & 55 & 60 \\
\hline & Extension & 72 & 90 \\
\hline & Cooling & 4 & - \\
\hline
\end{tabular}

\section{Statistical analysis}

All data were analyzed using SPSS 17.0 software, and the data are reported as means \pm SD. Hardy-Weinberg equilibrium was used for analyzing the representative of the population, and the genotype and allele frequencies were calculated. The differences between the groups were analyzed by the chi-square and the Fisher exact tests. The associations among genotypes and alleles were calculated by reckoning the odds ratio (OR) and $95 \%$ credibility interval (CI) from logistic regression analyses. The Hardy-Weinberg equilibrium was calculated using the chi-square test. $\mathrm{P}<0.05$ was considered statistically significant.

\section{RESULTS}

\section{Serum TNF- $\alpha$ level}

As shown in Table 3, the mean serum TNF- $\alpha$ level in the OA-TB patients was 283.16 $\pm 51.68 \mathrm{ng} / \mathrm{L}$, which was significantly higher than that in controls $(122.54 \pm 54.65 \mathrm{ng} / \mathrm{L} ; \mathrm{P}<$ $0.05)$. Additionally, the average TNF- $\alpha$ level in females was higher than in males, among both the OA-TB patients and healthy volunteers.

Genetics and Molecular Research 15 (4): gmr15048937 
Table 3. Serum TNF- $\alpha$ level in OA-TB patients and healthy volunteers.

\begin{tabular}{l|c|c|c}
\hline \multirow{2}{*}{ Group } & \multicolumn{3}{|c}{ TNF- $\alpha$ level (ng/L, means \pm SD) } \\
\cline { 2 - 4 } & Males (cases) & Females (cases) & Total (cases) \\
\hline OA-TB patients & $279.60 \pm 51.28(72)$ & $284.96 \pm 56.40(48)$ & $283.16 \pm 51.68(120)$ \\
\hline Healthy volunteers & $122.06 \pm 54.38(70)$ & $123.53 \pm 59.30(30)$ & $122.54 \pm 54.65(100)$ \\
\hline$t$ & 13.16 & 11.69 & 23.03 \\
\hline P value & $<0.05$ & $<0.05$ & $<0.05$ \\
\hline
\end{tabular}

TNF- $\alpha$, tumor necrosis factor- $\alpha$; OA-TB, osteoarticular tuberculosis.

\section{Genotype and allele frequencies of $T N F-\alpha-308,-238$, and -863}

All $T N F-\alpha$ SNPs were genotyped for the 120 OA-TB patients and 100 healthy volunteers. All of the SNPs in the patients and controls accorded with the Hardy-Weinberg equilibrium $(\mathrm{P}>0.05)$.

As shown in Table 4, the TNF- $\alpha-308$ G/A gene polymorphism was associated with predisposition to OA-TB. Higher frequency of the TNF- $\alpha-308$ GG genotype was observed in healthy volunteers $(91.0 \%)$ than in the OA-TB patients $(79.2 \%)$, indicating that this genotype was a protective factor against $\mathrm{OA}-\mathrm{TB}(\mathrm{OR}=0.405,95 \% \mathrm{CI}=0.147-0.657, \mathrm{P}=0.007)$. In contrast, lower frequency of the $T N F-\alpha-308$ GA genotype was observed in the healthy volunteers $(8.0 \%)$ than in the OA-TB patients $(20.8 \%)$, indicating that it was associated with an increased risk of $\mathrm{OA}-\mathrm{TB}(\mathrm{OR}=3.112,95 \% \mathrm{CI}=1.520-6.343, \mathrm{P}=0.003)$. Additionally, higher frequency of the TNF- $\alpha-308$ allele (A) in the OA-TB patients (10.4\%), than in the healthy volunteers $(5.0 \%)$, indicated that this allele was a risk factor for $\mathrm{OA}-\mathrm{TB}(\mathrm{OR}=3.109$, $95 \% \mathrm{CI}=1.676-6.538, \mathrm{P}=0.006)$.

Table 4. Genotype and allele frequencies of TNF- $\alpha$ in OA-TB patients $(\mathrm{N}=120)$ and healthy volunteers $(\mathrm{N}=100)$.

\begin{tabular}{|c|c|c|c|c|c|}
\hline SNP & Allele or genotype & OA-TB patients (\%) & Healthy volunteers (\%) & OR $(95 \% \mathrm{CI})$ & P value \\
\hline \multicolumn{6}{|l|}{ TNF- $\alpha-308$} \\
\hline \multirow[t]{2}{*}{ Allele frequency } & $\mathrm{G}$ & $215(89.6)$ & $190(95.0)$ & Ref. & - \\
\hline & $\mathrm{A}$ & $25(10.4)$ & $10(5.0)$ & $3.109(1.676-6.538)$ & $0.006^{*}$ \\
\hline \multirow[t]{3}{*}{ Genotype frequency } & GG & $95(79.2)$ & $91(91.0)$ & $0.405(0.147-0.657)$ & $0.007 *$ \\
\hline & GA & $25(20.8)$ & $8(8.0)$ & $3.112(1.520-6.343)$ & $0.003^{*}$ \\
\hline & AA & $0(0)$ & $1(1.0)$ & - & - \\
\hline \multicolumn{6}{|l|}{ TNF- $\alpha-238$} \\
\hline \multirow[t]{2}{*}{ Allele frequency } & $\mathrm{G}$ & $200(83.3)$ & $177(88.5)$ & Ref. & - \\
\hline & $\mathrm{A}$ & $40(16.7)$ & $23(11.5)$ & $0.890(0.528-1.542)$ & 0.920 \\
\hline \multirow[t]{3}{*}{ Genotype frequency } & GG & $87(72.5)$ & $82(82.0)$ & Ref. & - \\
\hline & GA & $26(21.7)$ & $13(13.0)$ & $0.906(0.544-1.673)$ & 0.653 \\
\hline & AA & $7(5.8)$ & $5(5.0)$ & - & - \\
\hline \multicolumn{6}{|l|}{ TNF- $\alpha-863$} \\
\hline \multirow[t]{2}{*}{ Allele frequency } & $\mathrm{C}$ & $235(97.9)$ & $193(96.5)$ & Ref. & - \\
\hline & $\mathrm{A}$ & $5(2.1)$ & $7(3.5)$ & $0.527(0.134-2.326)$ & 0.437 \\
\hline \multirow[t]{3}{*}{ Genotype frequency } & $\mathrm{CC}$ & $116(96.7)$ & $94(94.0)$ & Ref. & - \\
\hline & $\mathrm{CA}$ & $3(2.5)$ & $5(5.0)$ & $0.589(0.149-1.886)$ & 0.464 \\
\hline & AA & $1(0.8)$ & $1(1.0)$ & - & - \\
\hline
\end{tabular}

$* \mathrm{P}<0.05$, statistically significant; TNF- $\alpha$, tumor necrosis factor- $\alpha$; OA-TB, osteoarticular tuberculosis; SNP, single nucleotide polymorphism; Ref., reference $=1$.

However, the allele and genotype frequencies of $T N F-\alpha-238$ and -863 did not differ significantly between the OA-TB patients and healthy volunteers, indicating that -238 and -863 were not associated with the risk of OA-TB.

Genetics and Molecular Research 15 (4): gmr15048937 


\section{Haplotype association analysis of $T N F-\alpha-308,-238$, and -863}

The haplotype association analysis of TNF- $\alpha$ SNPs $(-308 /-238 /-863)$ is shown in Table 5. Higher frequency of the TNF- $\alpha$ AGA haplotype was observed in the OA-TB patients $(12.1 \%)$ than in the healthy volunteers (3.5\%), indicating that $T N F-\alpha$ AGA was a risk factor for OA-TB $(\mathrm{OR}=4.201,95 \% \mathrm{CI}=1.80-9.91, \mathrm{P}=0.010)$. The other haplotypes were not associated with OA-TB $(\mathrm{P}>0.05)$.

Table 5. Haplotype association analysis for $T N F-\alpha-308,-238$, and -863 in OA-TB patients and healthy volunteers.

\begin{tabular}{l|c|c|c|c}
\hline Haplotype & OA-TB patients (\%) & Healthy volunteers (\%) & OR (95\%CI) & P value \\
\hline TNF- $\alpha$ SNPs-308/-863/-238 & \multicolumn{5}{|c}{} \\
\hline GGC & $197(82.1)$ & $174(87.0)$ & Ref. & - \\
\hline GAC & $1(0.4)$ & $3(1.5)$ & $0.430(0.09-2.98)$ & 0.602 \\
\hline GGA & $3(1.3)$ & $2(1.0)$ & $1.862(0.30-14.5)$ & 0.684 \\
\hline GAA & $4(1.7)$ & $3(1.5)$ & $0.695(0.14-2.98)$ & 0.710 \\
\hline AGC & $4(1.7)$ & $6(3.0)$ & $0.576(0.17-2.03)$ & 0.428 \\
\hline AAC & $0(0)$ & $1(0.5)$ & - & - \\
\hline AGA & $29(12.1)$ & $7(3.5)$ & $4.201(1.80-9.91)$ & $0.010^{*}$ \\
\hline AAA & $2(0.8)$ & $4(2.0)$ & $0.731(0.18-4.36)$ & 0.712 \\
\hline
\end{tabular}

$* \mathrm{P}<0.05$, statistically significant; TNF- $\alpha$, tumor necrosis factor- $\alpha$; OA-TB, osteoarticular tuberculosis; SNPs, single nucleotide polymorphisms; Ref., reference $=1$.

\section{DISCUSSSION}

OA-TB is caused by M. tuberculosis, which can diffuse to the bone and joints through the blood and lymphatic system, leading to abundant blood concentration of these pathogens and osteoarticular necrosis with heavy microbial burden (Onaitis et al., 2006). A previous study showed that TNF- $\alpha$ can bind to the receptor on the osteoclast precursors and can directly or indirectly regulate its differentiation, activation, and apoptosis (McKenna et al., 2006).

In our research, we studied the association of SNPs of $T N F-\alpha-308,-238$, and -863 with OA-TB and found that the serum TNF- $\alpha$ level in the OA-TB patients was $283.16 \pm 51.68$ $\mathrm{ng} / \mathrm{L}$, which was significantly higher than that in controls $(122.54 \pm 54.65 \mathrm{ng} / \mathrm{L} ; \mathrm{P}<0.05)$. The average TNF- $\alpha$ level in females was higher than that in males, among both the OA-TB patients and healthy volunteers. This indicated that the serum TNF- $\alpha$ level was related to the pathogenesis of OA-TB.

Of the $T N F-\alpha$ SNPs, we found that only the $T N F-\alpha-308 \mathrm{G} / \mathrm{A}$ gene polymorphism was associated with predisposition to OA-TB, whereas $T N F-\alpha-238$ and -863 did not differ significantly between the OA-TB patients and healthy volunteers, indicating that $T N F-\alpha-308$ was a risk factor for OA-TB. The TNF- $\alpha-308$ GG genotype was present at a higher frequency in the healthy volunteers $(91.0 \%)$ than in the OA-TB patients $(79.2 \%)$, thereby behaving as a protective factor against $\mathrm{OA}-\mathrm{TB}(\mathrm{OR}=0.405,95 \% \mathrm{CI}=0.147-0.657, \mathrm{P}=0.007)$. The $T N F-\alpha-308$ GA genotype was present at a lower frequency in the healthy volunteers $(8.0 \%)$ than in the OA-TB patients $(20.8 \%)$, indicating that it was associated with increased risk of $\mathrm{OA}-\mathrm{TB}(\mathrm{OR}=3.112,95 \% \mathrm{CI}=$ $1.520-6.343, \mathrm{P}=0.003$ ). Additionally, the $T N F-\alpha-308$ allele (A) was more frequently observed in the OA-TB patients $(10.4 \%)$ than in the healthy volunteers $(5.0 \%)$, indicating that it was a risk factor for $\mathrm{OA}-\mathrm{TB}(\mathrm{OR}=3.109,95 \% \mathrm{CI}=1.676-6.538, \mathrm{P}=0.006)$.

The results of studies on the association of $T N F-\alpha$ SNPs with TB vary, probably due to the different types of TB and their geographic distribution. Vejbaesya et al. (2007) found 
that $T N F-\alpha-308$ and -238 are not associated with pulmonary TB in Thai patients, whereas Merza et al. (2009) observed that $T N F-\alpha-308$ allele (A) is associated with susceptibility to pulmonary TB in Iranian patients. According to Li (2015), $T N F-\alpha-308$ is associated with OATB in Tibetans in Qinghai area, whereas $T N F-\alpha-238$ is not; this is similar to our results. This indicated that the two OA-TB afflicted populations, Tibetan and Chinese, have similar TNF- $\alpha$ SNPs, due to which the results were similar.

There have been many reports on the association of $T N F-\alpha-308,-238$, and -863 with different diseases, such as hepatitis B virus infection (Du et al., 2006; Basturk et al., 2008) and breast cancer (Yang et al., 2011). In our study, we combined the three SNPs and the haplotype association analysis of $T N F-\alpha$ SNPs $(-308 /-238 /-863)$ showed that the TNF- $\alpha$ AGA haplotype was present at a higher frequency in the OA-TB patients $(12.1 \%)$ than in the healthy volunteers $(3.5 \%)$, indicating that it was a risk factor for $\mathrm{OA}-\mathrm{TB}(\mathrm{OR}=4.201,95 \% \mathrm{CI}=$ $1.80-9.91, \mathrm{P}=0.010)$. The other haplotypes were not associated with $\mathrm{OA}-\mathrm{TB}(\mathrm{P}>0.05)$. This indicated that $T N F-\alpha$ AGA $(-308 /-238 /-863)$ could be used in the detection, prevention, and prognosis of OA-TB.

However, owing to the use of a small sample size and specific population in our study, further investigations on the association of $T N F-\alpha$ SNPs with OA-TB are required.

In conclusion, OA-TB patients had higher serum TNF- $\alpha$ level than healthy individuals. The $T N F-\alpha-308 \mathrm{G} / \mathrm{A}$ gene polymorphism was associated with a predisposition to OA-TB, with lower $T N F-\alpha-308$ GG but higher $T N F-\alpha-308$ GA, $T N F-\alpha-308$ allele (A), and $T N F-\alpha$ AGA $(-308 /-238 /-863)$ frequencies in OA-TB patients than in healthy individuals. Therefore, $T N F-\alpha$ SNPs could aid clinical detection, prevention, and prognosis of OA-TB.

\section{Conflict of interest}

The authors declare no conflict of interest.

\section{ACKNOWLEDGMENTS}

All the fund and financial support in this study were obtained from the individual donations of Professor Zhi-Kun Zhang.

\section{REFERENCES}

Basturk B, Karasu Z, Kilic M, Ulukaya S, et al. (2008). Association of TNF-alpha -308 polymorphism with the outcome of hepatitis B virus infection in Turkey. Infect. Genet. Evol. 8: 20-25. http://dx.doi.org/10.1016/j.meegid.2007.09.001

Cheng SM (2011). China Tuberculosis Research. Proceedings of Chinese Anti-Tuberculosis Association National Conference. Chin. J. Antituberculosis. 2011, 33: 525-526.

D'Alfonso S and Richiardi PM (1994). A polymorphic variation in a putative regulation box of the TNFA promoter region. Immunogenetics 39: 150-154. http://dx.doi.org/10.1007/BF00188619

Du T, Guo XH, Zhu XL, Li JH, et al. (2006). Association of TNF-alpha promoter polymorphisms with the outcomes of hepatitis B virus infection in Chinese Han population. J. Viral Hepat. 13: 618-624. http://dx.doi.org/10.1111/j.1365$\underline{2893.2006 .00731 . x}$

Garg RK and Somvanshi DS (2011). Spinal tuberculosis: a review. J. Spinal Cord Med. 34: 440-454. http://dx.doi.org/10 $.1179 / 2045772311$ Y.0000000023

Heesen M, Kunz D, Wessiepe M, van der Poll T, et al. (2004). Rapid genotyping for tumor necrosis factor-alpha (TNFalpha)-863C/A promoter polymorphism that determines TNF-alpha response. Clin. Chem. 50: 226-228. http://dx.doi. org/10.1373/clinchem.2003.022962

Genetics and Molecular Research 15 (4): gmr15048937 
Li DC (2015). Relationship between tumor necrosis factor- a 308 and 238 polymorphisms and osteoarticular tuberculosis in Tibetans. Chin. Gen. Practice. 18: 645-648.

Li Z, Xue J, Yan S, Chen P, et al. (2013). Association between tumor necrosis factor-a 308G/A gene polymorphism and silicosis susceptibility: a meta-analysis. PLoS One 8: e76614. http://dx.doi.org/10.1371/journal.pone.0076614

Madan-Lala R, Sia JK, King R, Adekambi T, et al. (2014). Mycobacterium tuberculosis impairs dendritic cell functions through the serine hydrolase Hip1. J. Immunol. 192: 4263-4272. http://dx.doi.org/10.4049/jimmunol.1303185

McKenna RJ, Jr., Houck W and Fuller CB (2006). Video-assisted thoracic surgery lobectomy: experience with 1,100 cases. Ann. Thorac. Surg. 81: 421-425, discussion 425-426. http://dx.doi.org/10.1016/j.athoracsur.2005.07.078

Merza M, Farnia P, Anoosheh S, Varahram M, et al. (2009). The NRAMPI, VDR and TNF-alpha gene polymorphisms in Iranian tuberculosis patients: the study on host susceptibility. Braz. J. Infect. Dis. 13: 252-256. http://dx.doi. org $/ 10.1590 / \mathrm{S} 1413-86702009000400002$

Onaitis MW, Petersen RP, Balderson SS, Toloza E, et al. (2006). Thoracoscopic lobectomy is a safe and versatile procedure: experience with 500 consecutive patients. Ann. Surg. 244: 420-425.

Pantelidis P, Lympany PA, Foley PJ, Fanning GC, et al. (1999). Polymorphic analysis of the high-affinity tumor necrosis factor receptor 2. Tissue Antigens 54: 585-591. http://dx.doi.org/10.1034/j.1399-0039.1999.540608.x

Raja A (2004). Immunology of tuberculosis. Indian J. Med. Res. 120: 213-232.

Tuli SM (2002). General principles of osteoarticular tuberculosis. Clin. Orthop. Relat. Res. 398: 11-19. http://dx.doi. org/10.1097/00003086-200205000-00003

Vejbaesya S, Chierakul N, Luangtrakool P and Sermduangprateep C (2007). NRAMP1 and TNF-alpha polymorphisms and susceptibility to tuberculosis in Thais. Respirology 12: 202-206. http://dx.doi.org/10.1111/j.1440-1843.2006.01037.x

Wilson AG, de Vries N, Pociot F, di Giovine FS, et al. (1993). An allelic polymorphism within the human tumor necrosis factor alpha promoter region is strongly associated with HLA A1, B8, and DR3 alleles. J. Exp. Med. 177: 557-560. http://dx.doi.org/10.1084/jem.177.2.557

World Health Organization (2013). Global tuberculosis report 2013. http://apps.who.int/iris/ bitstream/10665/91355/1/9789241564656_eng.pdf.

Yang Y, Feng R, Bi S and Xu Y (2011). TNF-alpha polymorphisms and breast cancer. Breast Cancer Res. Treat. 129: 513-519. http://dx.doi.org/10.1007/s10549-011-1494-2

Genetics and Molecular Research 15 (4): gmr15048937 